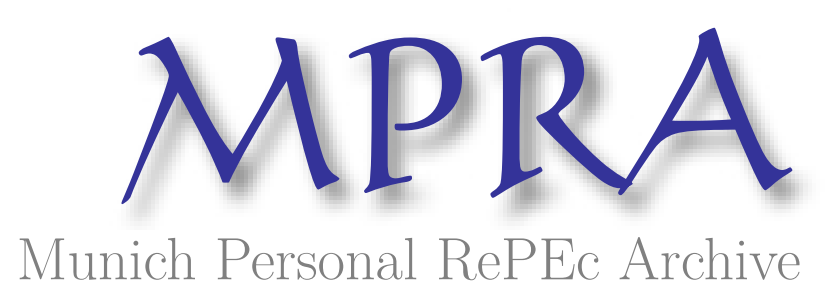

\title{
Atomic bombs and the long-run effect on trust: Experiences in Hiroshima and Nagasaki.
}

Yamamura, Eiji

10 February 2012

Online at https://mpra.ub.uni-muenchen.de/36805/

MPRA Paper No. 36805, posted 20 Feb 2012 14:06 UTC 


\title{
Atomic bombs and the long-run effect on trust: Experiences in Hiroshima and Nagasaki
}

\author{
Eiji Yamamura ${ }^{1}$
}

Department of Economics, Seinan Gakuin University, 6-2-92 Sawara-ku Nishijin

Fukuoka 814-8511, Japan

\begin{abstract}
Hiroshima and Nagasaki in Japan are the only cities in the world that have experienced an atomic bomb attack. This paper explores how this devastating experience affected victims' tendency to trust others. Individual-level data were used to examine the long-term influence of experiencing an atomic bomb on individuals' trust. After controlling for individual characteristics, I obtained the following key findings. Individuals who experienced the attack were more likely to trust others. Furthermore, estimation based on a subsample revealed that victims of the Hiroshima nuclear bomb were more likely to trust others than those born in other areas of Japan before World War II. This implies that experiencing an historically traumatic event in 1945 strongly influenced individuals' trust in others even at the beginning of the 21 st century. It follows from this that the effect of this devastating experience was enduring and had a long-term influence on individuals' values.
\end{abstract}

JEL classification: N45, N95, Z13

Keywords: Atomic bomb; Trust; Hiroshima; Nagasaki; War.

${ }_{1}^{1}$ Department of Economics, Seinan Gakuin University, 6-2-92 Sawara-ku, Fukuoka 814-8511, Fukuoka. Japan. E-mail address:yamaei@seinan-gu.ac.jp 


\section{Introduction}

On March 11, 2011, the Fukushima nuclear accident triggered by a devastating earthquake and tsunami caused tremendous damage in Japan and affected views about nuclear energy around the world (Yamamura, 2012). ${ }^{2}$ It is the second time Japan has experienced hardship related to nuclear energy. In 1945, 65 years prior to the Fukushima accident, atomic bombs were dropped on Hiroshima and Nagasaki in the western part of Japan. Immediately after the attacks, the most terrible scenes in human history were observed in these cities. However, the shock of the bombs dissipated, and the populations of Hiroshima and Nagasaki returned to a pre-war growth trend (Davis and Weinstein, 2002) and were rebuilt during the post-World War II period. The bombings sharply reduced production factors such as physical capital and labor, hindering economic growth. There seem to be various reasons for the rebuilding of areas where the atomic bombs were dropped. For instance, there is the argument that disaster becomes the catalyst for innovation and "disasters also provide an opportunity to update the capital stock, thus encouraging the adoption of new technologies" (Skidmore and Toya, 2002; 665). Positive externalities such as agglomeration economies appeared to have contributed to growth of the bombed areas as well. ${ }^{3}$

Apart from these factors, trust is also considered a key determinant of economic growth (e.g., Algan and Cahuc, 2010; Beugelsdijk et al., 2004; Dincer and Uslaner, 2010; Putnam, 1993; Zak and Knack, 2001). Trust plays a critical role in making market economies function well because market transactions cannot be facilitated when sellers do not trust buyers and vice versa. Castillo and Carter (2005) found that the impact of disastrous shocks was significantly reduced by social trust, which facilitates economic recovery. ${ }^{4}$ When closely investigating economic development, a question arises regarding how and under what conditions people have a tendency to trust others. A number of researchers have examined the determinants of trust (e.g., Alesina and La Frrara, 2002; Bidner and Francois, 2011; Bjørnskov, 2006b; Chan, 2007; Uslaner, 2002; Yamamura, 2008). However, few works have attempted to investigate the effect of traumatic experiences on trust, with the exception of Alesina and La Ferrara (2002) and Bellows and Miguel (2006).

The Nazi Holocaust during World War II was also a horrible disaster. Acemoglu et al. (2011) explored the long-run effect of the Holocaust in Russia and found that it changed the social structure, leading to worse economic and political outcomes than the collapse of the Soviet Union. In contrast, existing studies on Sierra Leone provide evidence that the experience of war has a positive effect on accumulation of social capital through, for instance, residents participating in community activities,

2 As a result of the Fukushima accident, the future of nuclear energy became a critical political issue (Kirman, 2012). Ferstl et al. (2011) found that the accident influenced the daily stock prices of German, French, and Japanese nuclear utilities

and alternative energy firms. Furthermore, disastrous events have a critical effect on the outcome of elections and policy in the United States (Eisensee and Strömberg, 2007; Kahn, 2007).

3 In the case of Hiroshima, the head office of Mazda Motor Corporation was located in that city and grew in the post-World War II period, causing agglomeration economies. 4 Bellows and Migual (2009) argued that social capital such as community and political participation played a role in economic recovery from the Sierra Leone war. 
joining local political groups, and voting (Bellows and Miguel, 2006, 2009). On the other hand, a case study of Vietnam showed that the United States bombing did not have long-term detrimental effects on economic conditions, including local poverty rates, consumption levels, and infrastructure. Brakman et al. (2004), using historical data from Germany, showed that bombing shock at most had a temporary effect on city growth in the post-World War II period in western Germany. ${ }^{5}$ Bozzoli et al. (2012), using data from Uganda, found that mass violent conflicts were correlated with pessimism about future prospects but had a different effect on expectations overtime. The long-term influence of disastrous experiences such as nuclear bombing on trust has not been examined, although existing works have explored the effect of the Chernobyl nuclear accident on student performance (Almond et al., 2009) and individual values about the environment (Berger, 2010). Therefore, it is of value to investigate how the atomic bombs influenced the degree of trust in Hiroshima and Nagasaki, given that trust appeared to contribute to the rebuilding of those cities. ${ }^{6}$

This paper explores the long-term effect on trust of experiencing an atomic bomb using the Japanese General Social Surveys (JGSS), which included more than 12,000 observations. I found that people who experienced the bomb were more likely to trust others. Field experiments are very useful in examining human behaviors and values related to social capital (e.g., Cassar et al., 2007; Castillo and Carter, 2003, 2005; Danielson and Holm, 2007; Fehr, 2009; Fehr and List, 2004). However, it is difficult for researchers to investigate the long-term effects of events such as war and bombing on trust using field experiments. Of course, it is impossible to conduct an atomic bomb experiment for the purpose of analyzing socioeconomic outcomes. Hence, survey data are very useful in analyzing the long-term effects of atomic bombs on individuals' values. Major findings of this paper through ordered probit estimation are (1) people who experienced an atomic bomb were more likely to trust others and (2) victims of the Hiroshima bomb were more likely to trust others than those born in other places in Japan before World War II.

The remainder of this paper is organized as follows. Testable hypotheses are proposed in Section 2. Section 3 provides an explanation regarding data and the empirical method used. Section 4 presents the estimation results and their interpretation. The final section offers some conclusions.

\section{Conditions in Hiroshima and Nagasaki and Hypotheses}

According to information provided by the Hiroshima Peace Memorial Museum, ${ }^{7}$ the first atomic bomb, which was dropped on Hiroshima on August 6, 1945, was powered by the splitting of 855 grams of uranium. The energy released was the equivalent of 15 kilotons of TNT. The bomb created a high-temperature, high-pressure fireball that grew to a diameter of approximately 410 meters one second after detonation. Large amounts of radioactive material fell as black rain, and a total of 350,000 people suffered the direct effects of the bombing. About

5 Brakman et al. (2004), however, showed that bombing shock had a permanent effect on city growth in eastern Germany.

6 Kasagi (2012) found that the atomic bomb dropped on Hiroshima had a detrimental effect on victims' mental health.

7 See http://www.hiroshima-spirit.jp/en/museum/index.html 
140,000 people were estimated to have died by the end of 1945 alone. All buildings in the area where the bomb was dropped were completely burnt down.

After the Hiroshima bombing, on August 9, 1945, a second atomic bomb was dropped, this time on Nagasaki. Energy emission was equivalent to 21 kilotons of TNT, which was almost two times larger than that in Hiroshima. In total, 73,884 people were dead and 74,909 people were injured as of December 1945 (Nagasaki Atomic Bomb Museum). ${ }^{8}$ Because of the hilly topology of Nagasaki and the fact that the bomb missed its target, the damage in Nagasaki was less than that in Hiroshima (Davis and Weinstein, 2002).

Disastrous events seem to have an effect on the degree of trust through two channels. First, "individuals who directly experienced violence during the recent Sierra Leone civil war are no different in terms of postwar socioeconomic status, but they display dramatically higher levels of political mobilization and engagement, as well as higher local public goods contributions, than non-victims. The gap we find between those who directly experienced violence and others provides evidence that personal experience is much more influential than mere observation in shaping subsequent behavior "(Bellows and Miguel, 2009; 1155). Similar evidence presented in an experimental study showed that individuals' own personal experiences influenced their behavior (Simonsohn et al., 2008). This suggests that individuals' preferences and values change when they directly suffer from a disastrous event such as war. Based on the argument above, Hypothesis 1 is postulated:

\section{Hypothesis 1: Experiencing an atomic bombing leads victims to trust others.}

Second, it is possible that disastrous events reinforce norm of trusting others within a community rather than affecting individual level of trust. For example, the percentage of households that suffered housing losses from Hurricane Mitch caused the people living in the damaged areas to trust others (Castillo and Carter, 2005). This implies that traumatic events influence the norm to trust others in the area, which in turn affects individual values. If this is true, people residing in damaged areas are more likely to trust others even if they were born after the disastrous event and thus did not personally experience it. This leads me to propose Hypothesis 2:

Hypothesis 2: Experiencing an atomic bomb forms the norm to trust others in the bombed area.

\section{Data and Methods}

\subsection{Data}

Individual-level data from JGSS were used in this paper. ${ }^{9}$ A two-stage stratified sampling method was used for the surveys. They were conducted throughout Japan beginning in 2000. The dataset used for this paper covers 2000, 2001, 2002, 2003,

\footnotetext{
8 See http://www1.city.nagasaki.nagasaki.jp/peace/english/abm/download/leaflet_e.pdf

9 Data for this secondary analysis, "Japanese General Social Surveys (JGSS), Ichiro

Tanioka," was provided by the Social Science Japan Data Archive, Information Center for Social Science Research on Japan, Institute of Social Science, The University of Tokyo.
} 
2005, 2006, and 2008. ${ }^{10}$ JGSS ask standard questions concerning an individual's characteristics via face-to-face interviews. The data include information related to generalized trust, marital status, age, gender, annual household income, ${ }^{11}$ years of schooling, age, prefecture of residence, and prefecture of residence at age 15. A Japanese prefecture is the equivalent of a state in the United States or a province in Canada. There are 47 prefectures in Japan. Data were collected from 22,796 adults between 20 and 89 years old. Respondents did not answer all of the survey questions. Therefore, data regarding some variables were not available, and the number of samples used in the regression estimations was reduced to 12,026.

The use of JGSS data in this paper has certain advantages. First, JGSS were designed as a Japanese counterpart to the General Social Survey (GSS) from the United States. Existing studies aimed at ascertaining the determinants of trust have used the GSS (Alesina and Ferrara, 2002). Hence, this paper provides findings that can be appropriately compared with data in the United States. Second, JGSS provide information that links place of residence during the pre-war period for those who were 15 years old with their trust level after approximately 60 years. However, "the GSS does not contain information on the place of origin of the respondent, neither in terms of birth nor in terms of previous residential location" (Alesina and La Ferrara, 2002, 225). Compared with the GSS, I appreciate the advantages of the JGSS, which enabled me to investigate the long-term influence of experiencing an atomic bomb on level of trust.

Variables used in the regression estimations are shown in Table 1. Definitions and mean comparisons of Hiroshima victims, Nagasaki victims, and others are provided. Hiroshima and Nagasaki victims were extracted from the whole sample in the following way. Information about place of residence (prefecture) at age 15 and place of residence (prefecture) at the time the surveys were conducted was obtained from JGSS. In this paper, I assumed that respondents continued to reside in the same place after age 15 if the residence was the same when surveys were conducted. Based on the years of the data studied, the victims were at least 15 years old when the bombs were dropped. Hence, they would have had a clear memory of the event, and the bombs were expected to have had a critical effect on respondents' values. However, the direct physical damage to people was primarily restricted to the cities of Hiroshima and Nagasaki. ${ }^{12}$ Hiroshima is in the western part of Hiroshima prefecture, and Nagasaki is in the southern part of Nagasaki prefecture. Apart from the cities of Hiroshima and Nagasaki, there was not extensive damage across the prefectures. Because of data limitations, it is not clear whether residents of Hiroshima and Nagasaki prefectures lived in the cities proper of Hiroshima and Nagasaki. Therefore, the definition of "victims" in this paper was not equivalent to those who physically suffered from the bombs. Even if residents of Hiroshima and

10 Surveys were not conducted in 2004 and 2007. Surveys were conducted in 2009 and 2010 , but the data were not available.

11 In the original dataset, annual earnings were grouped into 19 categories, and we assumed that everyone in each category earned the midpoint value. For the top category of " 23 million yen and above," I assumed that everybody earned 23 million yen. Of the 12,026 observations used in the regression estimations, there were only 119 observations in this category. Therefore, the problem of top-coding should not be an issue here.

12 Opinions vary about the areas in which people suffered physically from the atomic bombs (Mainichi Newspaper, January 13, 2012). 
Nagasaki prefectures in 1945 were not physically affected by the bombs, the disastrous events in their prefecture of residence is assumed to have had a serious psychological impact on them. However, results of this paper should be cautiously interpreted based on this assumption.

The number of respondents who continued to reside in Hiroshima and Nagasaki were 418 and 263, respectively. I extracted those who were born before 1930 from a subsample of those who continued to reside in these two prefectures. ${ }^{13}$ These residents were thought to reside in the prefectures in 1945 and thus were victims of the bombs, including 47 in Hiroshima and 25 in Nagasaki. Furthermore, among the victims, 40 in Hiroshima and 21 in Nagasaki responded to the questions related to the variables used in this paper.

As exhibited in Table 1, there was a difference in means for various variables between the victims of atomic bombs and others. Mean age was 79.7 for Hiroshima victims and 79.2 for Nagasaki victims, which reflects the definition of the victims. Concerning marital status, the rate of those currently married was $82.0 \%$ for others. The marriage rates for victims were $50.0 \%$ (Hiroshima) and $57.1 \%$ (Nagasaki), remarkably lower than that for others. I interpret this as reflecting the fact that people at about age 80 are likely to become widowed. Furthermore, $45.0 \%$ (Hiroshima) and $33.3 \%$ (Nagasaki) of victims were males, perhaps indicative of a shorter male life span. Household income was 468,000 yen (Hiroshima) and 304,000 yen (Nagasaki), sharply lower than the 621,000 yen for others. This indicates that most victims of the atomic bombs were retired. Years of schooling were 9.1 (Hiroshima) and 8.5 (Nagasaki), less than the 12.2 years for others. This might be because victims of the bombs were the pre-war generation when, in general, people tended to work after completing compulsory education. Rates of those who trusted other people were $22.5 \%$ (Hiroshima) and $23.8 \%$ (Nagasaki), slightly higher than the $22.2 \%$ for others. This implies that experiencing an atomic bomb led victims to trust others. For closer examination, a regression analysis was conducted. Results are discussed in the following section.

\subsection{Trust and its definition}

According to Putnam (2000), social capital is defined as the features of a social organization such as community participation, networks and norms, and social trust. These features play a critical role in facilitating coordination and cooperation. More precisely, networks and norms, and social trust have different functions. Therefore, interpretation of social capital depends on the context and situation. This has caused ambiguity and criticism regarding its measurement and definition (e.g., Bjørnskov, 2006a; Durlauf, 2002; Paldam, 2000; Sobel, 2002). Therefore, for an in-depth study, it is necessary to focus on just one aspect of social capital. Bellows and Miguel (2009) focused on the impact of war on social capital captured mainly by community and political participation. Although this paper has a similar motivation as the Bellows and Miguel paper, the mechanism by which disastrous events influence trust, rather than other aspects of social capital, is analyzed here.

Existing works have put an emphasis on dividing trust into generalized and

13 If respondents were born after 1931, I could not obtain information about their place of residence in 1945 even if they resided in Hiroshima or Nagasaki at age 15. This is because they became 15 years old after 1946 . 
particularized types (Bjørnskov, 2006; Uslaner, 2002). "The central idea distinguishing generalized from particularized trust is how inclusive your moral community is." (Uslaner, 2002; 26-27). People with generalized trust tend to have positive views toward both their own in-group and out-groups. Contrarily, people with particularized trust tend to have positive views of their own in-group but a negative attitude toward groups to which they do not belong. Generalized trust can be extended to strangers, whereas particularized trust might be restricted to a well-established personal network. Hence, generalized trust is thought to reduce the transaction cost between people belonging to different groups, causing markets to function well. On the other hand, particularized trust enhances non-market economic activities. An efficient market mechanism is required for recovery from devastating situations such as those in Hiroshima and Nagasaki. The role played by generalized trust is thus considered to have been more important than particularized trust for the recovery in Hiroshima and Nagasaki in the post-war period. Hence, this paper used a proxy for generalized trust as the dependent variable rather than particularized trust.

With respect to measurement of generalized trust, considered a crucial dependent variable, respondents were asked "Generally speaking, would you say that most people can be trusted?" The possible responses to this question were "No", "Depends", and "Yes".

\subsection{Econometric framework and estimation strategy}

For the purpose of examining the hypotheses proposed previously, the estimated function of the baseline model takes the following form:
Trust $_{i}=\alpha_{1}$ Hiroshima victims $_{i}+\alpha_{2}$ Nagaski victims $_{i}+\alpha_{3}$ Hiroshima dummy $_{i}+$ $\alpha_{4}$ Nagasaki dummy $_{i}+\alpha_{5}$Household income $_{i}+\alpha_{6}$ Age $_{i}+\alpha_{7}$ Married $_{i}+\alpha_{8}$ Years of Schooling ${ }_{i}+\alpha_{9}$ Male dummy ${ }_{i}+u_{i}$,

where Trust $i$ represents the dependent variable in individual $i$. Regression parameters are represented by $\alpha$. As explained earlier, the value of trust ranges from 1-3: 1 (No), 2 (Depends), 3 (Yes). Hence the ordered probit model was used to conduct the estimations.

Among these responses, "Depends" calls for careful interpretation. It is unclear whether "Depends" can be considered an intermediate category. It may include a number of respondents who would have answered in other categories if other possible responses were included in the questionnaire. For alleviating any bias arising from this, in the alternative specification, I restricted the sample to those who responded "Yes" or "No" to the question about trust where Trust takes either 1 (Yes) or 0 (No) and thus is the dummy variable. Hence, the probit model was used for the robustness check of the ordered probit model. The error term is represented by $u_{\text {im. }}$ It is reasonable to assume that the observations may be spatially correlated within a prefecture, as the preference of one agent may well relate to the preference of another in the same prefecture. To consider such spatial correlation in line with this assumption, I used the Stata cluster command and calculated z-statistics using robust standard errors. The advantage of this approach is that the magnitude of spatial correlation can be unique to each prefecture.

The key variables used to examine the Hypotheses proposed in the previous section are as follows. Hiroshima victims and Nagasaki victims were included to 
capture the individual experiencing of atomic bombs. If experiencing an atomic bomb leads people to trust others, their coefficient signs become positive. To capture the effect of atomic bombs on the norm in bombed areas, Hiroshima dummy and Nagasaki dummy were incorporated. If coefficients of these dummy variables take the positive sign after controlling for individual experience of an atomic bomb, then an atomic bomb leads people who lived in the bombed areas to trust others. That is, the norm to trust others was possibly formed by the atomic bombs.

Consistent with Alesina and Ferrara (2002), various individual characteristics were incorporated as control variables. ${ }^{14}$ Household income was included to capture economic condition. Years of Schooling was a proxy for human capital. Standing in society and relationships with other people seemed to vary according to age, marital status, and sex. These factors are thought to influence individual values.

\section{Estimation Results}

\subsection{Results of baseline estimations}

The estimation results of the baseline model are presented in Tables 2(a) and (b). In Table 2(a), victims of nuclear bombs were divided into Hiroshima victims and Nagasaki victims. In Table 2(b), victims of nuclear bombs were not divided. In each Table, Columns (1)-(3) present results of the ordered probit model; columns (4)_(6) present results of the probit model.

I see from columns (2) and (5) of Table 2(a) that Hiroshima victims and Nagasaki victims yielded the positive sign and were statistically significant at the $1 \%$ level. As shown in columns (1) and (4), these results did not change when Hiroshima dummy and Nagasaki dummy were included. This result was consistent with Hypothesis 1. Column (1) shows that coefficient values for Hiroshima victims and Nagasaki victims were 0.35 and 0.33 , respectively. Column (4) reveals that coefficient values for Hiroshima victims and Nagasaki victims were 0.16 and 0.17 , respectively, implying that the marginal effect of a nuclear bomb on victims of Hiroshima was almost the same as that for the Nagasaki bomb. In contrast, Hiroshima dummy and Nagasaki dummy yielded the negative sign in all estimations. Furthermore, with the exception of Hiroshima dummy shown in column (6), all were statistically significant. This was not in line with Hypothesis 2. I interpreted it as follows. As discussed previously, Hiroshima dummy and Nagasaki dummy capture the norm to trust in the bombed areas. It is possible that the norm was rooted in a profound cultural climate and thus already existed before World War II. Hence, it is not clear whether the norm was formed by the dropping of the atomic bombs.

All control variables exhibited statistical significance in all columns. The significant positive sign of coefficients for Household income and Years of schooling reflects that a successful experience makes individuals more prone to trust others. The significant positive sign was exhibited in coefficients for Age and Male. These results for Household income, Years of schooling, Age and Male were in line with

14 Alesina and La Ferrara (2002) included an ethnic fragmentation index to capture the heterogeneity of community. Japan is characterized by racial homogeneity, and thus ethnic fragmentation is unlikely to have affected the results. Hence, that index was not incorporated in this paper. 
data in the United States (Alesina and La Ferrara, 2002). The significant positive sign for Married suggests that married people are likely to be connected to an extensive and open social network because they belong not only to their own network, but also to their spouse's network. Connection with others seems to lead married people to trust others.

Results of alternative specifications reported in Table 2(b) were similar to results in Table 2(a). Hence, the results of Table 2(a) were robust to alternative specifications.

\subsection{Results of estimations using subsamples}

Baseline estimations were conducted by using a sample covering all generations and areas in Japan. As discussed earlier, Hiroshima dummy and Nagasaki dummy were included to control for effects of the norm. In addition, I used a subsample of Hiroshima and Nagasaki prefectures, which consisted not only of victims of the bombs but also non-victims living in these prefectures. The trust norm was considered to affect the value of trust of the respondents included in the subsample. That is, the norm effect would be common to all respondents of the subsample. Estimation using the subsample allowed me to scrutinize the effect of experiencing the bomb on trust.

In Table 3, all control variables used in Table 2(a) and (b) were included as independent variables although results were not reported. I see from column (1) and (3) that Hiroshima victims and Nagasaki victims produced the positive sign and were statistically significant at the $1 \%$ level. In column (1), coefficient values were 0.45 for Hiroshima victims and 0.42 for Nagasaki victims. Furthermore, the marginal effect exhibited in column (4) was 0.30, the same for Hiroshima victims and Nagasaki victims. Hence, there seemed to be no difference in the effect of nuclear bombs on level of trust between victims of Hiroshima and Nagasaki. Columns (2) and (4) show the significant positive sign for Hiroshima and Nagasaki victims. Hence, there was a remarkable difference in the effect of an atomic bomb on trust between victims and non-victims within Hiroshima and Nagasaki prefectures. This result from the subsample of respondents from these prefectures suggests that the atomic bombs dropped on Hiroshima and Nagasaki changed the trust level of the people who experienced the atomic bomb in 1945 but did not form a norm to trust others. This is in line with findings in Sierra Leone (Bellows and Miguel, 2009).

The cohort of those born before 1930 is equivalent to the cohort of those who were over 15 years old in 1945 . Thus, respondents in the cohort should have had a clear memory of the atomic bombs even if they did not reside in Hiroshima or Nagasaki. In other words, the people belonging to the cohort shared the memory of World War II. The victims of the bombs also belonged to this cohort. Therefore, level of trust was possibly influenced by experiencing war rather than an atomic bomb. For the purpose of identifying the effect of the bombs, the subsample consisting of the cohort was used to conduct the estimations.

As presented in columns (2) and (4) of Table 4, the significant positive sign for Hiroshima and Nagasaki victims reveals that the victims were more inclined to trust others, compared with non-victims belonging to the same cohort. I see from columns (1) and (3) in Table 4 that coefficient signs for Hiroshima victims and Nagasaki victims were positive. Hiroshima victims were statistically significant at 
the $1 \%$ level, whereas Nagasaki victims became statistically insignificant. Furthermore, in column (1), the coefficient value was 0.17 for Hiroshima victims, approximately four times larger that for Hiroshima victims. Column (4) reveals that the marginal effect for Hiroshima victims was 0.10 , which is two and a half times larger than the 0.04 for Nagasaki victims. The difference in effect of the nuclear bombs between Hiroshima and Nagasaki is interesting. Perhaps the difference in damage caused by the bombs led to a difference in their effect on trust. That is, the more serious the damage was, the more likely victims were to trust others. Furthermore, there was no significant difference between Nagasaki victims and non-victims belonging to the same cohort. Results in Table 4 indicate that the effect of the Nagasaki bomb on trust did not differ between victims and non-victims within the same cohort. Considering the results of Tables 2 to 4 together leads me to assert that Hypothesis 1 was strongly supported, but Hypothesis 2 was not supported.

The finding based on subsample estimation reveals that people born in Hiroshima before World War II were more likely to trust others than those born in other places in Japan before World War II. The reason Hiroshima victims were more inclined to trust others was that experiencing the atomic bomb influenced their individual values, not just that they were more likely to be alive. On the other hand, this does not hold for Nagasaki victims. That is, the regression results enabled me to identify the reason for Hiroshima victims' tendency to trust. However, this was not the case for Nagasaki victims. This implies that the greater damage from the Hiroshima bomb resulted in the different effect of the bombs on victims' values in the two cities.

\section{Conclusions}

In human history, only those who resided in Hiroshima and Nagasaki in August 1945 have been victims of atomic bombs. Despite disastrous damage, Hiroshima was rebuilt during the post-World War II period (Davis and Weinstein, 2002). Based on individual level data from JGSS for 2000-2008, this paper attempts to explore the long-term influence of atomic bombs on victims' individual level of trust, which seemed to be a key factor in the rebuilding of these cities.

After controlling for individual characteristics, I obtained the following key findings. People who experienced an atomic bomb were more likely to trust others. Furthermore, estimation based on a subsample revealed that victims of the Hiroshima nuclear bomb were more likely to trust others than those born in other places in Japan before World War II. This implies that experiencing this traumatic historical event in 1945 strongly influenced individuals' trust even at the beginning of the 21st century. The contribution of this paper is that it shows a disastrous event, such as the atomic bombing, can continue to facilitate trust over the long-term.

The JGSS were designed as a Japanese counterpart to the GSS used in existing works to examine trust in the United States (Alesina and Ferrara, 2002). Therefore, this paper provides interesting evidence comparable with that in the United States. The findings in this paper are not consistent with evidence provided by Alesina and La Ferrara (2002) that showed personal trauma can reduce social capital. However, these findings are consistent with evidence presented by Bellows and Miguel (2009) that showed personal trauma can increase social capital. Alesina and LaFerrara used a trauma dummy for estimation (equal to 1 if the individual had suffered a 
major negative experience in the past year). Recent traumas like divorce, disease, accidents, and financial misfortune were captured by the dummy. These types of trauma are clearly different from experiencing an atomic bomb. The trauma dummy captured a short-term effect, while the experiences in Hiroshima and Nagasaki captured a long-term effect. Furthermore, some experiences such as divorce are considered endogenous, whereas experiencing an atomic bomb is considered exogenous. The most important point is that the trauma dummy in Alesina and LaFerrara's study captured individual experiences. Experiencing an atomic bomb was an event all the people alive in Hiroshima and Nagasaki at that time had in common. The Sierra Leone war, which enhanced community and political participation, shares a similarity with Hiroshima and Nagasaki in that the people of Sierra Leone collectively experienced war rather than individually (Bellows and Miguel, 2009). From this I derive the argument that social capital such as trust or community participation is accumulated through the collective experience of a disastrous event rather than through individual traumatic experiences.

"Victims" of the atomic bombs included those who did not directly suffer from the bombs but resided in areas surrounding where the bombs were dropped. This is different from the work of Bellows and Miguel (2009) who found a distinct difference within the same area between victims who directly suffered from war and others. Japan is a racially and culturally homogenous society, which is remarkable different from the heterogeneous societies in many African countries, including Sierra Leone. Hence, the social structure possibly contributes to different outcomes of disastrous events.

There were only 61 respondents residing in Hiroshima and Nagasaki in 1945 who provided information related to variables in this study, even though the whole sample was over 10,000. That is, the sample size of victims of the atomic bombs was very small. This is in part because the victims were very old, and many were deceased when the surveys were conducted. Respondents who were victims had survived about 60 years after the bombings. Hence, because of limitations of the data, the estimation results inevitably suffer from selection bias. To provide more certain and confirmatory evidence, it is necessary to collect ample historical data in Japan to conduct the estimation. This remaining issue requires attention in future studies. 


\section{References}

Acemoglu, D., Hassan, T.A., Robinson, J.A., 2011. Social structure and development: A legacy of the Holocaust in Russia. Quarterly Journal of Economics 126, 895-946.

Alesina, A., La Ferrara, E., 2002. Who trusts others? Journal of Public Economics 85 (2), 207-234.

Algan, Y., Cahuc, P., 2010. Inherited trust and growth. American Economic Review 100 (5), 2060-2092.

Almond, D., Edlund, E., Palme, M., 2009. Chernobyl's subclinical legacy: Pre-natal exposure to radioactive fallout and school outcomes in Sweden. Quarterly Journal of Economics 124 (4), 1729-1772.

Bellows, J., Miguel, E., 2006. War and institutions: New evidence from Sierra Leone. American Economic Review 96 (2), 394-399.

Bellows, J., Miguel, E., 2009. War and local collective action in Sierra Leone. Journal of Public Economics 93, 1144-1157.

Berger, E.M., 2010. The Chernobyl disaster, concern about the environment, and life satisfaction. Kyklos 63, 1-8.

Beugelsdijk, S., de Groot, H.L.F., van Schaik, A., 2004. Trust and economic growth: a robustness analysis. Oxford Economic Papers 56, 118-134.

Bidner, C., Francois, P., 2011. Cultivating trust: Norms, institutions and the implication of scale. The Economic Journal 121, 1097-1129.

Bjørnskov, C., 2006a. The multiple facets of social capital. European Journal of Political Economy 22, 22-40.

Bjørnskov, C., 2006b. Determinants of generalized trust: A cross-country comparison. Public Choice 130, 1-21.

Bozzoli, C., Brück, T., Muhumuza, T., 2012. Does war influence individual expectations? Economics Letters 113, 288-291.

Brakman, S., Garrestern, H., Schramm, M., 2004. The strategic bombing of cities in Germany in World War II and its impact on city growth. Journal of Economic Geography 4 (1), 1-18.

Carmil, D., Breznitz, S., 1991. Personal trauma and world view-are extremely stressful experiences related to political attitudes, religious beliefs, and future orientation? Journal of Traumatic Stress 4 (3), 393-405.

Cassar, A., Crowley, L., Wydick, B., 2007. The effect of social capital on group loan repayment: Evidence from field experiments. The Economic Journal 117, F85-F106.

Castillo, M., Carter, M., 2003. Identifying social effects with economic field experiments. Unpublished results, University of Wisconsin.

Castillo, M., Carter, M., 2005. Coping with disaster: Morals, markets, and mutual insurance-Using economic experiments to study recovery from Hurricane Mitch, in: Barrett, C. (ed.), The Social Economics of Poverty: On Identities, Communities, Groups and Networks. Routledge, New York, pp.

Chan, K.S., 2007. Trade, social values, and the generalized trust. Southern Economic Journal 73, 733-753.

Danielson, A.J., Holm, H.J., 2007. Do you trust your brethren? Eliciting trust attitudes and trust behavior in a Tanzanian congregation. Journal of Economic Behavior and Organization 62, 225-271.

Davis, D.R., Weinstein, D., 2002. Bones, bombs, and break points: the geography of 
economic activity. American Economic Review 92 (5), 1269-1289.

Dincer, O., Uslaner, E., 2010. Trust and growth. Public Choice 142 (1), 59-67.

Durlauf, S.N., 2002. On the empirics of social capital. The Economic Journal 122 , F459-F479.

Eisensee, T., Strömberg, D., 2007. News droughts, news floods, and U.S. disaster relief. Quarterly Journal of Economics 122 (2), 693-728.

Fehr, E., 2009. On the economics and biology of trust. Journal of the European Economic Association 7 (2-3), 235-266

Fehr, E., List. J.A., 2004. The hidden costs and returns of incentives-trust and trustworthiness among CEOs, Journal of the European Economic Association 2 (5), 743-771.

Fehr, E., Schmidt, K., 1999. A theory of fairness, competition, and cooperation. Quarterly Journal of Economics 114 (3), 817-868.

Ferstl, R., Utz, S., Wimmer, M., 2011. The effect of the Japan 2011 disaster on nuclear and alternative energy stocks worldwide: An event study. Mimeo.

Hayami, Y., 2001. Development Economics: From Poverty to the Wealth of Nations, second ed. Oxford University Press, New York.

Kahn, M., 2007. Environmental disasters as risk regulation catalysts? The role of Bhopal, Chernobyl, Exxon Valdez, Love Canal, and Three Mile Island in shaping U.S. environmental law. Journal of Risk and Uncertainty 35 (1), 17-43.

Kirman, A., 2012. Letter from France: The politics of nuclear energy. Royal Economic Society Newsletter 156, 3-4.

Kasagi, F., 2012. Report on the health and values of A-bomb survivors (in Japanese) (Genbaku Taikensha-tou Kenko Ishiki Chosa hokoku). Mimeo. (http://www.mhlw.go.jp/stf/shingi/2r98520000020pbe-att/2r98520000020plt.pdf (Accessed February 12, 2012).

Miguel, E., Roland, G., 2011. The long run impact of bombing Vietnam. Journal of Development Economics 96 (1), 1-15.

Paldam, M., 2000. Social capital: one or many? Definition and measurement. Journal of Economic Surveys, 14, 629-653.

Punamaki, R.L, Quota, S., El Sarraj, E., 1997. Relationships between traumatic events, children's gender, political activity, and perceptions of parenting styles. International Journal of Behavioral Development 21 (1), 91-109.

Putnam, R., 1993. Making Democracy Work: Civic Traditions in Modern Italy. Princeton University Press, Princeton, NJ.

Putnam, R., 2000. Bowling Alone: The Collapse and Revival of American Community. Simon and Schuster, New York.

Simonsohn, U., Karlsson, N., Loewenstein, G., Ariely, D., 2008. The tree of experience in the forest of information: Overweighing experienced relative to observed information. Games and Economic Behavior 62 (1), 263-286.

Skidmore, M., Toya, H., 2002. Do natural disasters promote long-run growth? Economic Inquiry 40 (4), 664-687.

Sobel, J., 2002. Can we trust social capital? Journal of Economic Literature 40, $139-154$.

Uslaner, E., 2002. The Moral Foundation of Trust. Cambridge University Press, Cambridge.

Yamamura, E., 2008. Determinants of trust in a racially homogeneous society. Economics Bulletin 26 (1), 1-9.

Yamamura, E., 2012. Effect of free media on views regarding nuclear energy after 
the Fukushima accident. Kyklos 65 (1), 131-140.

Zak, P.J., Knack, S., 2001. Trust and growth. The Economic Journal 111, 295-321. 
Table 1

Basic statistics of variables used for Hiroshima and Nagasaki victims and others.

\begin{tabular}{|c|c|c|c|c|}
\hline & Definitions & $\begin{array}{c}\text { Hiroshima } \\
\text { victims }\end{array}$ & $\begin{array}{c}\text { Nagasaki } \\
\text { victims }\end{array}$ & Others \\
\hline Trust & $\begin{array}{l}\text { Range of values 1-3: } 1 \text { (No), } 2 \text { (Depends), } 3 \text { (Yes) } \\
\text { (Percentage of those who chose "3" reported in this row) }\end{array}$ & 22.5 & 23.8 & 22.2 \\
\hline $\begin{array}{l}\text { Household } \\
\text { income }\end{array}$ & Average household income in a prefecture (millions of yen) & $\begin{array}{l}468 \\
(543)\end{array}$ & $\begin{array}{l}304 \\
(278)\end{array}$ & $\begin{array}{c}621 \\
(419)\end{array}$ \\
\hline Age & & $\begin{array}{l}79.7 \\
(5.34)\end{array}$ & $\begin{array}{l}79.2 \\
(5.24)\end{array}$ & $\begin{array}{c}53.3 \\
(15.2)\end{array}$ \\
\hline Married & 1 if respondent was currently married, otherwise $0(\%)$ & 50.0 & 57.1 & 82.0 \\
\hline $\begin{array}{l}\text { Years of } \\
\text { schooling }\end{array}$ & & $\begin{array}{c}9.1 \\
(2.1)\end{array}$ & $\begin{array}{l}8.5 \\
(1.8)\end{array}$ & $\begin{array}{l}12.2 \\
(2.5)\end{array}$ \\
\hline Male & 1 if respondent was male, otherwise $0(\%)$ & 45.0 & 33.3 & 48.9 \\
\hline Observations & & 40 & 21 & 11992 \\
\hline
\end{tabular}

Notes: Numbers are mean values for household income, age, and years of schooling. Numbers in parentheses are standard deviations. Numbers are percentages for trust, married, and male. 
Table 2(a) Baseline model.

\begin{tabular}{|c|c|c|c|c|c|c|}
\hline & \multicolumn{3}{|c|}{$\begin{array}{l}\text { Ordered probit model } \\
\text { Dependent variable: Trust, } 1 \text { (No) } 3 \text { (Yes) }\end{array}$} & \multicolumn{3}{|c|}{$\begin{array}{l}\text { Probit model } \\
\text { Dependent variable: dummy variable that takes } 1 \text { if } \\
\text { Trust is } 3 \text { or } 0 \text { if Trust is } 1\end{array}$} \\
\hline & (1) & (2) & (3) & (4) & (5) & (6) \\
\hline Hiroshima victims & $\begin{array}{l}0.35^{* * *} \\
(13.2)\end{array}$ & $\begin{array}{l}0.30 * * * \\
(10.6)\end{array}$ & & $\begin{array}{l}0.16^{* * *} \\
(10.5)\end{array}$ & $\begin{array}{l}0.14^{* * *} \\
(8.31)\end{array}$ & \\
\hline Nagasaki victims & $\begin{array}{l}0.33^{* * *} \\
(13.9)\end{array}$ & $\begin{array}{l}0.22^{* * *} \\
(7.43)\end{array}$ & & $\begin{array}{l}0.17^{* * *} \\
(12.4)\end{array}$ & $\begin{array}{l}0.12^{* * *} \\
(7.30)\end{array}$ & \\
\hline Hiroshima dummy & $\begin{array}{c}-0.04^{* * *} \\
(-4.54)\end{array}$ & & $\begin{array}{r}-0.02 * * \\
(-2.04)\end{array}$ & $\begin{array}{c}-0.03^{* * *} \\
(-3.58)\end{array}$ & & $\begin{array}{l}-0.01 \\
(-1.25)\end{array}$ \\
\hline Nagasaki dummy & $\begin{array}{l}-0.11^{* * *} \\
(-6.59)\end{array}$ & & $\begin{array}{l}-0.09 * * * \\
(-5.32)\end{array}$ & $\begin{array}{l}-0.07 * * * \\
(-5.79)\end{array}$ & & $\begin{array}{l}-0.05^{* * *} \\
(-4.19)\end{array}$ \\
\hline Household income & $\begin{array}{l}0.24^{*} 10^{3 * * *} \\
(6.29)\end{array}$ & $\begin{array}{l}0.24^{*} 10^{3 * * *} \\
(6.25)\end{array}$ & $\begin{array}{l}0.24^{*} 10^{3 * * *} \\
(6.22)\end{array}$ & $\begin{array}{l}0.16^{*} 10^{3 * * *} \\
(6.49)\end{array}$ & $\begin{array}{l}0.16^{*} 10^{3 * * *} \\
(6.51)\end{array}$ & $\begin{array}{l}0.16^{*} 10^{3 * * *} \\
(6.50)\end{array}$ \\
\hline Age & $\begin{array}{l}0.002^{* *} \\
(2.47)\end{array}$ & $\begin{array}{l}0.002^{* *} \\
(2.48)\end{array}$ & $\begin{array}{l}0.002 * * * \\
(2.60)\end{array}$ & $\begin{array}{l}0.001^{* *} \\
(2.43)\end{array}$ & $\begin{array}{l}0.001^{* *} \\
(2.45)\end{array}$ & $\begin{array}{l}0.001^{* *} \\
(2.56)\end{array}$ \\
\hline Married & $\begin{array}{l}0.06 * * \\
(2.17)\end{array}$ & $\begin{array}{l}0.06 * * \\
(2.15)\end{array}$ & $\begin{array}{l}0.06 * * \\
(2.09)\end{array}$ & $\begin{array}{l}0.05^{* *} \\
(2.52)\end{array}$ & $\begin{array}{l}0.05^{* *} \\
(2.50)\end{array}$ & $\begin{array}{l}0.05^{* *} \\
(2.43)\end{array}$ \\
\hline Years of schooling & $\begin{array}{l}0.05^{* * *} \\
(11.3)\end{array}$ & $\begin{array}{l}0.05^{* * *} \\
(11.2)\end{array}$ & $\begin{array}{l}0.05^{* * *} \\
(11.9)\end{array}$ & $\begin{array}{l}0.03^{* * * *} \\
(10.4)\end{array}$ & $\begin{array}{l}0.03^{* * * *} \\
(10.4)\end{array}$ & $\begin{array}{l}0.03^{* * * *} \\
(10.3)\end{array}$ \\
\hline Male & $\begin{array}{l}0.10^{* * * *} \\
(4.80)\end{array}$ & $\begin{array}{l}0.10^{* * * *} \\
(4.79)\end{array}$ & $\begin{array}{l}0.10^{* * * *} \\
(4.79)\end{array}$ & $\begin{array}{l}0.04^{* *} \\
(2.41)\end{array}$ & $\begin{array}{l}0.04^{* *} \\
(2.41)\end{array}$ & $\begin{array}{l}0.04^{* *} \\
(2.41)\end{array}$ \\
\hline $\begin{array}{l}\text { Log pseudo-likelihood } \\
\text { Observations }\end{array}$ & $\begin{array}{r}-10116 \\
12026\end{array}$ & $\begin{array}{l}-10116 \\
12026\end{array}$ & $\begin{array}{l}-10115 \\
12026\end{array}$ & $\begin{array}{l}-2438 \\
4065\end{array}$ & $\begin{array}{l}-2437 \\
4065\end{array}$ & $\begin{array}{l}-2437 \\
4065\end{array}$ \\
\hline
\end{tabular}

Notes: Values are coefficients for columns (1)-(3) and marginal effects for (4)-(6). Numbers in parentheses are z-statistics calculated using robust standard errors clustered in the prefecture. $* *$ and $* * *$ indicate significance at the $5 \%$ and $1 \%$ levels, respectively. In all estimations, constant, proxy for size of residential area, and year dummies are included as independent variables but are not reported because of space limitations. 
Table 2(b) Baseline model.

\begin{tabular}{|c|c|c|c|c|c|c|}
\hline & \multicolumn{3}{|c|}{$\begin{array}{l}\text { Ordered probit model } \\
\text { Dependent variable: Trust, 1(No) } 3 \text { (Yes) }\end{array}$} & \multicolumn{3}{|c|}{$\begin{array}{l}\text { Probit model } \\
\text { Dependent variable: dummy variable that takes } 1 \text { if } \\
\text { Trust is } 3 \text { or } 0 \text { if Trust is } 1\end{array}$} \\
\hline & (1) & (2) & (3) & $(4)$ & (5) & (6) \\
\hline $\begin{array}{l}\text { Hiroshima and } \\
\text { Nagasaki victims }\end{array}$ & $\begin{array}{l}0.34 * * * \\
(13.5)\end{array}$ & $\begin{array}{l}0.27 * * * \\
(7.01)\end{array}$ & & $\begin{array}{l}0.17 * * * \\
(11.6)\end{array}$ & $\begin{array}{l}0.14^{* * *} \\
(7.28)\end{array}$ & \\
\hline $\begin{array}{l}\text { Hiroshima and } \\
\text { Nagasaki dummy }\end{array}$ & $\begin{array}{l}-0.07 * * * \\
(-2.99)\end{array}$ & & $\begin{array}{l}-0.04^{*} \\
(-1.83)\end{array}$ & $\begin{array}{l}-0.04 * * * \\
(-2.77)\end{array}$ & & $\begin{array}{l}-0.02 \\
(-1.58)\end{array}$ \\
\hline Household income & $\begin{array}{l}0.24^{*} 10^{3 * * *} \\
(6.22)\end{array}$ & $\begin{array}{l}0.24^{*} 10^{3 * * *} \\
(6.25)\end{array}$ & $\begin{array}{l}0.24^{*} 10^{3 * * * *} \\
(6.22)\end{array}$ & $\begin{array}{l}0.16^{*} 10^{3 * * *} \\
(6.49)\end{array}$ & $\begin{array}{l}0.16^{*} 10^{3 * * *} \\
(6.51)\end{array}$ & $\begin{array}{l}0.16^{*} 10^{3 * * *} \\
(6.51)\end{array}$ \\
\hline Age & $\begin{array}{l}0.002^{* *} \\
(2.47)\end{array}$ & $\begin{array}{l}0.002^{* *} \\
(2.48)\end{array}$ & $\begin{array}{l}0.002^{* * *} \\
(2.60)\end{array}$ & $\begin{array}{l}0.001^{* *} \\
(2.44)\end{array}$ & $\begin{array}{l}0.001^{* *} \\
(2.45)\end{array}$ & $\begin{array}{l}0.001^{* *} \\
(2.57)\end{array}$ \\
\hline Married & $\begin{array}{l}0.06 * * \\
(2.18)\end{array}$ & $\begin{array}{l}0.06 * * \\
(2.15)\end{array}$ & $\begin{array}{l}0.06 * * \\
(2.10)\end{array}$ & $\begin{array}{l}0.05^{* *} \\
(2.53)\end{array}$ & $\begin{array}{l}0.05 * * \\
(2.49)\end{array}$ & $\begin{array}{l}0.05 * * \\
(2.44)\end{array}$ \\
\hline Years of schooling & $\begin{array}{l}0.05^{* * *} \\
(11.3)\end{array}$ & $\begin{array}{l}0.05^{* * *} \\
(11.2)\end{array}$ & $\begin{array}{l}0.05^{* * *} \\
(12.0)\end{array}$ & $\begin{array}{l}0.03^{* * *} \\
(10.4)\end{array}$ & $\begin{array}{l}0.03^{* * *} \\
(10.4)\end{array}$ & $\begin{array}{l}0.03^{* * *} \\
(10.3)\end{array}$ \\
\hline Male & $\begin{array}{l}0.10^{* * *} \\
(4.80)\end{array}$ & $\begin{array}{l}0.10^{* * *} \\
(4.79)\end{array}$ & $\begin{array}{l}0.10^{* * *} \\
(4.79)\end{array}$ & $\begin{array}{l}0.04^{* *} \\
(2.41)\end{array}$ & $\begin{array}{l}0.04^{* *} \\
(2.41)\end{array}$ & $\begin{array}{l}0.04^{* *} \\
(2.41)\end{array}$ \\
\hline $\begin{array}{l}\text { Log pseudo-likelihood } \\
\text { Observations }\end{array}$ & $\begin{array}{r}-10115 \\
12026\end{array}$ & $\begin{array}{l}-10116 \\
12026\end{array}$ & $\begin{array}{l}-10116 \\
12026\end{array}$ & $\begin{array}{l}-2437 \\
4065\end{array}$ & $\begin{array}{l}-2437 \\
4065\end{array}$ & $\begin{array}{l}-2437 \\
4065\end{array}$ \\
\hline
\end{tabular}

Notes: Values are coefficients for columns (1)-(3) and marginal effects for (4)-(6). Numbers in parentheses are z-statistics calculated using robust standard errors clustered in the prefecture. ${ }^{*}, * *$, and $* * *$ indicate significance at the $10 \%, 5 \%$, and $1 \%$ levels, respectively. In all estimations, constant, proxy for size of residential area, and year dummies are included as independent variables but are not reported because of space limitations. 
Table 3 Subsample of respondents who currently lived in Hiroshima and Nagasaki prefectures.

\begin{tabular}{|c|c|c|c|c|}
\hline & \multicolumn{2}{|c|}{$\begin{array}{l}\text { Ordered probit model } \\
\text { Dependent variable: Trust, } 1 \text { (No) } 3 \text { (Yes) }\end{array}$} & \multicolumn{2}{|c|}{$\begin{array}{l}\text { Probit model } \\
\text { Dependent variable: dummy variable that takes } 1 \text { if } \\
\text { Trust is } 3 \text { or } 0 \text { if Trust is } 1\end{array}$} \\
\hline & (1) & (2) & (3) & $(4)$ \\
\hline Hiroshima victims & $\begin{array}{c}0.45^{* * * *} \\
(8.64)\end{array}$ & & $\begin{array}{c}0.30 * * * \\
(9.23)\end{array}$ & \\
\hline Nagasaki victims & $\begin{array}{l}0.42^{* * * *} \\
(42.1)\end{array}$ & & $\begin{array}{l}0.30^{* * *} \\
(21.9)\end{array}$ & \\
\hline $\begin{array}{l}\text { Hiroshima and } \\
\text { Nagasaki victims }\end{array}$ & & $\begin{array}{l}0.44^{* * *} \\
(8.52)\end{array}$ & & $\begin{array}{l}0.31^{* * *} \\
(4.39)\end{array}$ \\
\hline $\begin{array}{l}\text { Log pseudo-likelihood } \\
\text { Observations }\end{array}$ & $\begin{array}{l}-373 \\
465\end{array}$ & -373465 & $\begin{array}{l}-81.9 \\
147\end{array}$ & $\begin{array}{c}-81.9 \\
147\end{array}$ \\
\hline
\end{tabular}


Table 4 Subsample of respondents born before 1930.

\begin{tabular}{|c|c|c|c|c|}
\hline & $\begin{array}{c}\text { Ordered probit model } \\
\text { Dependent variable: Trust }\end{array}$ & \multirow{2}{*}{$\begin{array}{c}1 \text { (No) } 3 \text { (Yes) } \\
(2)\end{array}$} & \multicolumn{2}{|c|}{$\begin{array}{l}\text { Probit model } \\
\text { Dependent variable: dummy variable that takes } 1 \text { if } \\
\text { Trust is } 3 \text { or } 0 \text { if Trust is } 1\end{array}$} \\
\hline & (1) & & (3) & (4) \\
\hline Hiroshima victims & $\begin{array}{l}0.17^{* * *} \\
(2.91)\end{array}$ & & $\begin{array}{l}0.10^{* * * *} \\
(2.82)\end{array}$ & \\
\hline Nagasaki victims & $\begin{array}{c}0.04 \\
(0.90)\end{array}$ & & $\begin{array}{c}0.04 \\
(0.92)\end{array}$ & \\
\hline $\begin{array}{l}\text { Hiroshima and } \\
\text { Nagasaki victims }\end{array}$ & & $\begin{array}{l}0.13^{* *} \\
(2.00)\end{array}$ & & $\begin{array}{l}0.08^{* *} \\
(1.98)\end{array}$ \\
\hline $\begin{array}{l}\text { Log pseudo-likelihood } \\
\text { Observations }\end{array}$ & $\begin{array}{l}-979 \\
1105\end{array}$ & $\begin{array}{l}979 \\
1105\end{array}$ & $\begin{array}{r}-255 \\
402\end{array}$ & $\begin{array}{c}-81.9 \\
402\end{array}$ \\
\hline
\end{tabular}

